\title{
Linear Regression Long-Term Energy Demand Forecast Modelling in Ogun State, Nigeria
}

\author{
ADE-IKUESAN, OO; *OYEDEJI, AO; OSIFEKO, MO \\ Department of Computer and Electrical Engineering, Olabisi Onabanjo University, Nigeria. \\ *Corresponding Author Email: oyedeji.ajibola@oouagoiwoye.edu.ng
}

\begin{abstract}
This study uses linear regression analysis technique to forecast the energy load demand in Ogun State and the population for a 10-year period. Energy Demand data for the state for the years 2016 and 2017 was obtained from Ibadan Electricity Distribution Company (IBEDC) and the population data collected from the National Population Commission. The result shows a population growth rate of 3.35\% per year. The Energy Consumption Demand should not rise above $1,365,024.72 \mathrm{MWh}$ for a population of $7,791,237$ by the year 2028 , showing an increase of $53 \%$ from $892,170.95 \mathrm{MWh}$. The result of this work is very useful to energy distribution company (IBEDC) for their operational and planning activities for continued satisfactory service delivery.
\end{abstract}

\section{DOI: https://dx.doi.org/10.4314/jasem.v23i4.28}

Copyright: Copyright (C) 2019 Ade-Ikuesan et al. This is an open access article distributed under the Creative Commons Attribution License (CCL), which permits unrestricted use, distribution, and reproduction in any medium, provided the original work is properly cited.

Dates: Received: 27 February 2019; Revised: 25 March 2019; Accepted 19 April 2019

Keywords: Load forecasting, Energy Demand, Long-Term Forecast, Linear Regression

The recognition of future energy consumption patterns is an important part of the planning, operation and exploration of Electrical Power System. Nigeria is a nation that is growing fast in terms of population and economic activities which calls for an increase in energy consumption (Ade-Ikuesan, et al., 2018a). It is therefore very vital to understand how expected scenarios in terms of population or economic growth can be translated into corresponding future energy usage patterns (Ade-Ikuesan, et al., 2018b). Load forecasting is a method used to estimate the load for a future time point from the available past data (Alfares and Nazeeruddin, 2002). A forecast is a prediction of the future values of data with the aid of previous or past data (Luis, et al., 2016). However, most extrapolative model forecasts assume that the past is a proxy for the future. Electric load and demand forecasting involve the projection of peak demand levels and overall energy consumption patterns to support an electric utility's future system and business operations. Load forecasting plays an important role in power system planning operation, control as well as energy management. Load forecasts can be divided into three categories short-time forecasts which are usually from one hour to one week, medium-term forecasts which are usually from a week to a year and long-term forecasts which are longer than a year (Hahn, et al., 2009). Due to a geometric increase in the global demand for energy long term load forecasting became more important which ranges between five to several years. In Nigeria and Ogun State specifically, energy supply is prone to a lot of challenges like a fault on distribution, vandalism and the main aim of this project is to forecast reliable data on Energy Consumption Demand information and the population of Ogun State for the next 10 years. Different models for forecasting include (i) Probabilistic, (ii) Exponential smoothing (iii) Regression, (iv) Time series and (v) Composite model forecasts, often involving expert forecasts (Lacir and Marcelo, 2008). This study employs a regression model to forecast for long term energy demand in Ogun State, Nigeria. Regression analysis is a statistical technique to analyse quantitative data to estimate model parameters and make forecasts. While energy demand is increasing arithmetically (8000MW per annum), in Nigeria, energy supply is on the other hand decreasing.

In (Idoniboyeobu, et al., 2018), an analysis of long term electric power load forecasting for a period of twenty years (20 years) in Nigeria power system using modified form of exponential regression model which shows a deviation between predicted energy demand(MW) and available power (or capacity allocated) with percentage error of $1.37 \%$ compared to existing model with $1.67 \%$. In (Idoniboyeobu and Ekanem, 2014) using Akwa Ibom State, Nigeria as a case study assessed the electricity load consumption and result obtained using the least square method and regression exponential analysis method has shown that by 2020 , the electricity load requirement shall increase to $247.84 \mathrm{MW}$ from 130MW IN 2011. (Alfares and 
Nazeeruddin, 2002) asserts that load forecasting is an integral process in the planning of operation of electric utilities and holds a great saving potential for electric utility corporations.

Load forecasting task is difficult due to the complex nature of loads which may vary depending on the seasons and the total consumption for two similar seasons. Difficulties getting accurate data on consumer behaviour due to changes in factors such as pricing and the corresponding demand based on such price change (Chae, et al., 2016). There are many techniques for load forecasting. listed the methods normally used for load forecasting as; (i) Extrapolation technique based on curve fitting to previous load data available, the load can be forecasted at any future point by calculating the trend curve function at that point with its main drawback been lack of flexibility as future load prediction depends entirely upon the past trend which may give erroneous results. (ii) Scheer's method approach to the problem of load forecasting was through the per-capital consumption of energy. The per-capita consumption of energy in all developing countries follows a unique pattern. (iii) End-use method directly estimates energy consumption by using extensive information on end use and end users, such as appliances, the customer use, their ages, sizes of houses. Statistical information about customers along with dynamic of changes is the basis for the forecast (Hong, et al., 2014). The objective of this study is to perform a linear regression analysis to forecast the energy load demand in Ogun State and the population for a 10 -year period.

\section{MATERIALS AND METHODS}

Regression Analysis: In statistical modelling, regression analysis is a set of statistical processes for estimating the relationships among variables, when the focus is on the relationship between a dependent variable and one or more independent variable(s) or predictors and is widely used for forecasting where its use has substantial overlap with the field of machine learning. Many techniques for carrying out regression have been developed (Mohamed and Bodger, 2005). Familiar methods such as linear regression and ordinary least squares regression are parametric, in that regression function is defined in terms of a finite number of unknown parameters that are estimated from the data (Bianco, et al., 2009). Nonparametric regression refers to techniques that allow the regression function to lie in a specified set of functions, which may be infinite-dimensional.

$$
\begin{aligned}
& \text { Regression equation } \quad y=a+b x \\
& \text { Intercept } a=\frac{\left(\sum Y\right)\left(\sum X 2\right)-\left(\sum X\right)\left(\sum X Y\right)}{N\left(\sum X 2\right)-\left(\sum X\right) 2}
\end{aligned}
$$

$$
\begin{aligned}
\text { Slope } b & =\frac{N\left(\sum X Y\right)-\left(\sum X\right)\left(\sum Y\right)}{N\left(\sum X 2\right)-\left(\sum X\right) 2} \\
& \text { Mean of the } x \text { data, } \bar{x}=\frac{\sum x}{n} \\
& \text { Mean of the } y \text { data, } \bar{y}=\frac{\sum y}{n}
\end{aligned}
$$

Where $x$ and $y$ the independent and dependent variables respectively are, $a$ is the intercept point of the regression line which is in the $\mathrm{y}$-axis, $b$ is the slope of the regression line also known as regression coefficient, $N$ is the number of values or elements, $X$ is the first score, $Y$ is the second score.

Demographic Information: Ogun state is a state in southwestern Nigeria, with the coordinates; $7^{0} 00^{\prime} \mathrm{N}$ $3^{0} 35^{\prime} \mathrm{E} / 7.000^{\circ} \mathrm{N} 3.583^{0}$ E. Ibadan Electricity Distribution Company (IBEDC) has 6 Business Hubs operating in the state with the regional office in Abeokuta. There are also six Transmission stations in the state which are Sagamu, Ijebu-Ode, Ojere, Papalanto, Ota and Oke-Aro 132/33/11/0.415KVA transmission stations. These Transmission stations feed 33KVA feeders and 27 injection substations owned by IBEDC which inter supply electricity to 47 $11 \mathrm{KVA}$ feeders across the state. The energy consumption/demand data collected on the six transmission stations for a year are summed up and used as the dependent variable and the population for that year as the independent variable.

The demographic data of Ogun State, Nigeria as contained in the population census of $21^{\text {st }}$ March 2006 is a made up of 1,864,907 males and 1,886,233 females. The total population stood at $3,751,140$. The projected population for the state in 2010 also stood at $5,217,700$. The projected population of the year 2018 was at a value $5,573,369$.

Data on monthly Energy consumption was collected for the year 2016 and 2017 while data on population was collected for the year 2016 to the year 2018 as shown in Tables 1 - 3 .

Methods: Using population as the independent variable, the need for population projection arises. The population data was modelled with Malthusian population growth equation which is given as;

$$
N_{t}=P_{o} e^{r t}
$$

Where $N_{t}=$ the number of people at a future date, $P_{o}=$ the present or initial population, $e=$ natural logarithm base of $2.17828, r=$ population growth rate $\frac{x_{2}-x_{1}}{x_{1}}, t=$ time. 
The population growth rate using 2016 population as $\mathrm{x}_{1}$ and 2017 population as $\mathrm{x}_{2}$, the growth rate gives $\frac{5,392,477-5,217,455}{5,217,455}=0.0335$. To get the population for 2019 with equation 6 , taking $t=1$ and $P_{o}$ as 2018 population, $\quad N_{t}=5,573,369 \times e^{0.0335 \times 1}=$
$5,763,239$. Using equation 6 , population data for 10 years is projected from 2019 to 2028 .

Table 1: Monthly Energy Consumption for year 2016 in MWh

\begin{tabular}{|c|c|c|c|c|c|c|}
\hline Month & $\begin{array}{c}\text { IJEUN } \\
\text { BH }\end{array}$ & $\begin{array}{c}\text { OLUMO } \\
\text { BH }\end{array}$ & $\begin{array}{c}\text { IJEBU } \\
\text { ODE BH }\end{array}$ & $\begin{array}{c}\text { SAGAMU } \\
\text { BH }\end{array}$ & ОТА ВН & $\begin{array}{c}\text { SANGO } \\
\text { BH }\end{array}$ \\
\hline January & $6,700.06$ & $7,089.80$ & $9,562.00$ & $10,012.12$ & $11,223.58$ & $13,130.70$ \\
\hline February & $7,245.90$ & $6,500.25$ & $8,891.00$ & $14,168.80$ & $16,820.69$ & $11,122.40$ \\
\hline March & $7,440.43$ & $6,534.68$ & $8,786.00$ & $13,502.45$ & $17,872.50$ & $10,870.60$ \\
\hline April & $8,567.03$ & $7,421.36$ & $9,657.00$ & $12,776.65$ & $16,291.75$ & $12,889.80$ \\
\hline May & $9,453.08$ & $8,700.91$ & $7,986.00$ & $14,708.80$ & $18,768.99$ & $14,989.90$ \\
\hline June & $9,769.92$ & $8,992.72$ & $6,894.20$ & $13,812.10$ & $19,488.66$ & $16,542.20$ \\
\hline July & $8,899.57$ & $9,676.37$ & $6,805.00$ & $16,519.62$ & $18,778.88$ & $15,654.10$ \\
\hline August & $6,689.78$ & $10,988.95$ & $5,960.80$ & $18,689.65$ & $20,553.63$ & $17,809.70$ \\
\hline September & $5,567.34$ & $8,097.48$ & $10,762.00$ & $16,007.70$ & $17,088.39$ & $15,109.60$ \\
\hline October & $7,270.12$ & $9,766.62$ & $12,117.80$ & $24,999.56$ & $18,445.61$ & $16,668.30$ \\
\hline November & $8,789.68$ & $9,665.84$ & $10,006.70$ & $22,432.85$ & $21,773.87$ & $18,707.58$ \\
\hline December & $9,459.77$ & $10,755.58$ & $9,818.20$ & $25,054.28$ & $23,603.57$ & $19,778.80$ \\
\hline Total & $95,852.68$ & $104,190.58$ & $107,246.70$ & $202,684.58$ & $220,710.12$ & $183,273.68$ \\
\hline Grand Total & \multicolumn{6}{|c|}{$913,958.32$} \\
\hline
\end{tabular}

\begin{tabular}{|c|c|c|c|c|c|c|}
\hline \multirow[b]{2}{*}{ Year 2017} & \multicolumn{5}{|c|}{$\begin{array}{l}\text { Ionthly Energy consumptio } \\
\text { OLUMO IJEBU }\end{array}$} & \multirow{2}{*}{$\begin{array}{l}\text { SANGO } \\
\text { BH }\end{array}$} \\
\hline & BH & BH & ODE BH & BH & ОТА ВН & \\
\hline January & $5,624.13$ & $7,356.30$ & $7,073.00$ & $11,241.70$ & $17,392.57$ & $12,039.00$ \\
\hline February & $6,302.97$ & $7,549.87$ & $6,742.00$ & $14,666.30$ & $17,949.95$ & $10,966.80$ \\
\hline March & $5,736.42$ & $6,852.44$ & $6,673.00$ & $13,851.30$ & $16,386.00$ & $8,619.90$ \\
\hline April & $7,189.02$ & $7,027.60$ & $8,241.00$ & $11,520.60$ & $18,241.73$ & $11,943.80$ \\
\hline May & $7,985.02$ & $8,965.36$ & $7,787.00$ & $14,078.80$ & $19,348.91$ & $13,254.80$ \\
\hline June & $9,749.24$ & $9,364.32$ & $7,824.00$ & $12,837.10$ & $18,768.55$ & $14,459.10$ \\
\hline July & $9,649.95$ & $9,631.27$ & $8,805.00$ & $18,169.60$ & $17,691.58$ & $13,204.10$ \\
\hline August & $8,189.82$ & $9,183.75$ & $8,839.00$ & $22,389.60$ & $18,963.74$ & $12,684.90$ \\
\hline September & $8,267.31$ & $8,975.48$ & $11,167.00$ & $16,137.70$ & $19,613.15$ & $12,888.60$ \\
\hline October & $7,677.64$ & $8,967.76$ & $10,319.00$ & $25,527.40$ & $19,132.61$ & $13,998.90$ \\
\hline November & $8,037.68$ & $9,046.83$ & $11,778.00$ & $19,692.85$ & $20,833.14$ & $16,057.60$ \\
\hline December & $9,745.67$ & $11,155.85$ & $9,081.00$ & $25,918.28$ & $22,621.59$ & $16,518.00$ \\
\hline Total & $94,155.00$ & $104,076.83$ & $104,329.00$ & $206,031.23$ & 226.943 .52 & $156,626.50$ \\
\hline Grand Total & & & & 0.95 & & \\
\hline
\end{tabular}

Table 3: Population of Ogun state

\begin{tabular}{ll}
\hline Year & Population \\
\hline 2016 & $5,217,455$ \\
2017 & $5,392,477$ \\
2018 & $5,573,369$ \\
\hline
\end{tabular}

Using equations $1-5$ with energy demand been the dependent variable" $y$ ", population representing the independent variable" $x " . x=5,217,455$ (Population for 2016) and $y=913,958.32 M W h$ (energy demand/ consumption for 2016), $\mathrm{n}=10$ (since we are forecasting for 10 years).

$$
\begin{gathered}
\text { Slope } b=\frac{(5,217,255)(913,395.32)-(10)(521,745.5 * 91,395.832)}{5,217,455^{2}-(10) 521,745.5^{2}}=0.1752 \\
\text { Intercept } a=91,395.832-(0.1752 \times 521,745.5)=-13.98
\end{gathered}
$$

Substituting the value for $\mathrm{a}=-13.98, \mathrm{~b}=0.1752$ into $\quad y=-13.98+0.1752 x \quad$ gives $\quad$ the regression equation 1 , we have

equation. (7) 
For $x=5,392,477$ (population for 2017), $y=$ $944,747.99 M W h$ which is the predicted energy demand for 2017 using equation 7.

For 2018 energy demand with $y=944,747.99$ and $x=5,392,477$

$\bar{y}=94,474.799, \bar{x}=539,247.7$

$$
\begin{gathered}
\text { Intercept } a=94,474.799-(0.1752) 539,247.7 \\
=-1.40
\end{gathered}
$$

The energy demand for year 2018 is $y=-1.40+$ $(0.1752)(5,573,369)=976.452 .85 M W h . \quad$ The

$r=\frac{10\left(8.55765 \times 10^{13}\right)-(72,893,525)(12,770,944)}{\sqrt{\left(\left(10 \times 4.8845 \times 10^{14}\right)-\left(5.31347 \times 10^{15}\right)\right)\left(\left(10 \times 1.4993 \times 10^{13}\right)-\left(1.63097 \times 10^{14}\right)\right)}}=0.99$

Error: The percentage error is a useful tool for determining the precisions of your calculations and model which is given as:

$\%$ error $=\frac{\text { calculated value }- \text { theoretical value }}{\text { theoretical value }} \times 100$

(9)

\section{RESULTS AND DISCUSSION}

A regression analysis approach was conducted on the yearly data consumption in Ogun state for the year 2016 and 2017 which was used to project data demand for 10 future years (from the year 2019 to 2028). This was done using an independent variable (Population) for the year 2016 and 2017, which was also projected for 10 years (2019-2028) using the Malthusian Population Growth Equation. Using the derived regression analysis equations above, the population and Energy Consumption Demand were projected and forecasted for the period of 2019-2028 and the results presented in Table 4. The results show a linear increase and the relationship between the projected population and Energy Consumption Demand forecast.

The projected population values show a $3.35 \%$ increase over the years (a space of 12 years interval), this being a constant as projected in the Malthusian Population Growth Equation. This also shows that the Malthusian model is reliable, and also the Regression process is repeated to calculate the energy demand for 10 years as shown in Table 4 .

Correlation: linear regression is the measure of the strength of the relationship between independent and dependent variables. The formula for the correlation coefficient is

$$
r=\frac{n \sum x y-\sum x \sum y}{\sqrt{\left(n \sum x^{2}-\left(\sum x\right) 2\right)\left(n \sum y^{2}-\left(\sum y\right) 2\right)}}
$$

Where: $\sum x=$ the sum of the independent variables: $\sum y$ $=$ the sum of dependent variables; $\sum x y=$ the sum of the dependent and independent variables; $\sum \mathrm{x}^{2}=$ the sum of the square of the independent variables; $\sum y^{2}=$ the sum of the square of the dependent variables; analysis is suitable for use of energy demand projection in Ogun state and Nigeria as a whole.

The result of this analysis shows that the total energy consumption in Ogun State per year may not go beyond 1,365,024.72 (MWh) by the year 2028 putting

\begin{tabular}{|c|c|c|}
\hline Year & $\begin{array}{l}\text { Population } \\
\text { Projected }\end{array}$ & $\begin{array}{l}\text { Energy Demand } \\
\text { Forecasted (MWh) }\end{array}$ \\
\hline 2018 & $5,573,369$ & $976,452.85$ \\
\hline 2019 & $5,763,239$ & $1,009,719.33$ \\
\hline 2020 & $5,959,578$ & $1,044,118.05$ \\
\hline 2021 & $6,162,606$ & $1,079,688.57$ \\
\hline 2022 & $6,372,550$ & $1,116,470.76$ \\
\hline 2023 & $6,589,646$ & $1,154,505.98$ \\
\hline 2024 & $6,814,139$ & $1,193,837.15$ \\
\hline 2025 & $7,046,279$ & $1,234,508.08$ \\
\hline 2026 & $7,286,328$ & $1,276,564.67$ \\
\hline 2027 & $7,534,554$ & $1,320,053.86$ \\
\hline 2028 & $7,791,237$ & $1,365,024.72$ \\
\hline
\end{tabular}
into consideration that population increase does not go beyond 7,791,237 by the year 2028 .

The Errors and Percentage Errors for the projected population and forecasted Energy Demand and actual data collected for Ogun State, Nigeria for the year 2016 to 2018 using equation 9 is as shown in Table 5. The maximum percentage error on the Energy Demand is $5.98 \%$ and the error for the projected error is $0.56 \%$. This shows the reliability of the Linear Regression Analysis approach due to the small percentage error calculated.

Table 5: Percentage Error for Population and Energy Demand

\begin{tabular}{lllllll}
\hline Year & $\begin{array}{l}\text { Given Energy } \\
\text { Demand (MWh) }\end{array}$ & $\begin{array}{l}\text { Projected Energy } \\
\text { Demand (MWh) }\end{array}$ & $\begin{array}{l}\text { Percentage error of } \\
\text { energy demand }(\%)\end{array}$ & $\begin{array}{l}\text { Given } \\
\text { population }\end{array}$ & $\begin{array}{l}\text { Projected } \\
\text { population }\end{array}$ & $\begin{array}{l}\text { Percentage error } \\
\text { of population }(\%)\end{array}$ \\
\hline 2016 & $913,915.32$ & $967,543.39$ & 5.87 & $5,217,455$ & $5,243,870$ & 0.51 \\
2017 & $892,190.95$ & $944,747.99$ & 5.89 & $5,392,477$ & $5,422,515$ & 0.56 \\
2018 & $921,860.76$ & $976,952.85$ & 5.98 & $5,576,184$ & $5,607,246$ & 0.56 \\
\hline
\end{tabular}


This model shows the relationship between the dependent and independent variable. The correlation between the dependent variables and independent variables for this study is 0.99 , which signifies a strong relationship between energy demand and population.

Conclusion: This work provides relevant data on the projected population and subsequently the forecasted Energy Demand for Ogun State, Nigeria for 2019 2028. This study has assisted the Electricity Distribution Institution in making appropriate decisions in providing necessary upgrades to the energy supply so as to meet up with the energy demand of customers thereby resulting in customer satisfaction.

Acknowledgements: The authors sincerely acknowledge the Ibadan Electricity Distribution Company (IBEDC), Abeokuta Regional Office and the National Population Commission for the data provided towards the success of this project.

\section{REFERENCES}

Ade-Ikuesan, OO; Omotoso, OO; Osifeko, MO; Okakwu, IK; Alao, PO (2018a). Probabilistic Long-Term Energy Consumption Forecast in Nigeria: Ado-Ekiti as a Case Study. Nigerian Research Journal of Engineering and Environmental Sciences. 3(2): 784-789.

Ade-Ikuesan, OO; Osifeko, MO; Okakwu, IK; Folaranmi, KS; Alao, PO (2018b). Prediction of Electricity Consumption Demand Pattern for 2018 in Ogun State, Nigeria. J. Appl. Sci. Environ. Manage. 22(6): 883-886.

Alfares, HK; Nazeeruddin, M (2002). Electric load forecasting: literature survey and classification of methods. International Journal of Systems Science. 33(1): 23-34.

Bianco, V; Manca, O; Nardini, S (2009). Electricity consumption forecasting in Italy using linear regression models. Energy. 34: 1413-1421.
Chae, YT; Horesh, R; Hwang, Y; Lee, YM (2016). Artificial neural network model for forecasting sub-hourly electricity usage in commercial buildings. Energy and Buildings. 111: 184-194.

Hahn, H; Meyer-Nieberg, S; Pickl, S (2009). Electric load forecasting methods: Tools for decision making. European Journal of Operational Research. 199: 902-907.

Hong, T; Pinson, P; Fan, S (2014). Global Energy Forecasting Competition 201. International Journal of Forecasting. 30: 357-363.

Idoniboyeobu, DC; Ekanem, MB (2014). Assessment of Electric Load Demand and Prediction of Future Load Demand: A Case Study of Akwa Ibom State of Nigeria. Asian Journal of Scientific Research. 7(4): 525-535.

Idoniboyeobu, DC; Ogunsakin, AJ; Wokoma, BA (2018). Forecasting of Electrical Energy Demand in Nigeria using Modified Form of Exponential Model. American Journal of Engineering Research. 7(1): 122-135.

Lacir, JS; Marcelo, CM (2008). Modeling and forecasting short-term electricity load: A comparison of methods with an application to Brazilian data. International Journal of Forecasting. 24: 630-644.

Luis, GB; Manuel, PC; Miguel, DC; Maria, DC (2016). An Application of Non-Linear Autoregressive Neural Networks to Predict Energy Consumption in Public Buildings. Energies. 9: 684-705.

Mohamed, Z; Bodger, P (2005). Forecasting electricity consumption in New Zealand using economic and demographic variables. Energy. 30: 1833-1843. 